\title{
Using Group Oral Presentations as a Formative Assessment in Teaching English for Vietnamese EFL Students
}

\author{
Vu Tran Le Hoai ${ }^{1 *}$ \\ ${ }^{1}$ Language Institution, Van Lang University, Ho Chi Minh City, Vietnam \\ *Corresponding author. Email: tranlehoaivu1303@gmail.com
}

\begin{abstract}
English is a compulsory subject at Van Lang University, and students studying at this University have to match the program outcome standard in English. To achieve this requirement, the students have to get IELTS 4.5 before they graduate. It requires that the students must achieve English ability equivalent to level B1, according to CEFR, to graduate. However, there are a great number of students at Van Lang University showing incompetence in English, especially in speaking. Thus, to enhance students' English competence, the researcher implemented a teaching method used as a formative assessment in classrooms, called group oral presentations (GOPs). This paper explores the attitudes and perceptions of both students and teachers on the method. The participants are 53 EFL students studying at Van Lang University and five teachers teaching General English. We used a questionnaire for students and interviews for teachers to find out the results. The findings revealed that most students have positive attitudes towards this teaching method, although some face problems when they make presentations in classrooms. Besides, most teachers claimed that GOPs assisted students in enhancing their speaking ability. However, employing this method too much made students who were not good at English less confident, even scared of speaking English. In general, even though there were some drawbacks, this method could be seen as an effective assessment that helped students improve their speaking ability.
\end{abstract}

Keywords: Group Oral Presentations, EFL students, Attitudes, Perceptions, Speaking ability, Cooperative Learning.

\section{INTRODUCTION}

In recent years, as a result of globalization and the significant development of the economy, English has increasingly become more and more necessary for Vietnamese, especially for students. In this day and age, most businesses or enterprises require their employees or applicants to have enough English competence, especially English speaking proficiency when working or applying for the given careers. In addition, according to MOET [21], the Vietnamese Government issued the National Foreign Language Project scheme for the 20082020 periods, which aims to improve teaching and learning English processes in Vietnam. Consequently, English has been considered a compulsory subject at schools and universities. In this context, Van Lang University has begun to teach English for all students for many years and applied the Program Outcome Standards on English competence for graduated students. According to this outcome standard, students majoring in
English have to achieve C1 level in English, and students not majoring in English are B1 level. To meet the demand, teachers have improved their teaching technique and assessments, and management has innovated educational circumstances and policies at Van Lang University. In particular, teachers play an important role in enhancing students' abilities. Besides employing various teaching techniques in the classroom, teachers should also consider assessment during the teaching process. However, in the past few years, due to discrepancies in using teaching techniques and assessment among teachers at the university, there are differences in English ability in general and students' speaking ability in particular among classes. As a result, when graduated, there were many students who did not equip themselves with sufficient English ability. In this paper, we will take consideration using group oral presentation as a formative assessment, which can be seen as a teaching technique to engage students in lessons, develop communication skills, and help students 
match the requirements of their future careers [24]. And then, we analyze its impacts on improving students' speaking ability at the university.

\section{LITERATURE REVIEW}

\subsection{A Brief Introduction on Assessment}

According to Brown [4], assessment is defined as "an ongoing process that encompasses a much wider domain" (p.5). It includes all occasions from answering a question in the classroom, giving comments up to and consisting of tests. Thus, it seems that assessment has a broader concept than tests. Similarly, Mihai [20] stated that assessment is "much more than tests and test scores" (p.22). In fact, the assessment includes all kinds of formal or informal feedback, comment, and testing. Mihai [20] also classified assessment clearly in accordance with intention, purpose, interpretation, and administration. Regarding intention, if an assessment is an unplanned comment, it can be informal. But, if it is prepared carefully, it can be formal. In regard to purpose, an assessment can be formative if it emphasizes learners' learning process. It can be summative if we use it to evaluate learners' learning outcomes after a period of the course. Regarding interpretation, an assessment can be used to compare the learning performance among students and the learning outcomes and performance of students with the content of the course. In terms of administration, an assessment can be used on a smallscale such as in classrooms, or on a large scale, such as nationwide.

\subsubsection{Principles of Second Language Assessment}

In his book, Brown [4] pointed out some fundamental assessment principles, including validity, reliability, practicality, authenticity, and wash-back. In terms of validity, Brown [4] also asserted that a test is valid when it only measures what it intends to be measured, does not measure anything else. Regarding reliability, Brown [4] said that if a test is reliable, it is consistent and dependable. If a reliable test is distributed to many students on the same or different occasions, the results of the test are always similar. Regarding practicality, Bachman and Palmer [2] defined practicality as "the relationship between the resources that will be required in the design, development, and use of the test and the resources that will be available for these activities" (p.36). Brown [4] also suggested that a practical test is a test that is not too much expensive, is administered easily, has a specific and time-efficient scoring/evaluation procedure. In regards to authenticity, Bachman and Palmer [2] defined authenticity as "the degree of correspondence of the characteristics of a given language test task to the features of a target language task" (p.23). Brown [4] also stated that an authentic test is a test that has some characteristics as follows: natural language in the text; contextualized items; meaningful, relevant, and interesting topics; thematic organization to items; realwork tasks. In terms of wash-back, according to Brown and Hudson [5], it is considered as "the effect of testing and assessment on the language teaching curriculum that is related to it" (p.667). Similarly, Hughes [13] indicated that wash-back is the influence of the test on teaching and learning. Thus, it can be both positive and negative effects.

\subsection{Types of Assessment}

According to Brown [4], assessment can be divided into two types according to the function of assessment: formative assessment and summative assessment.

\subsubsection{Formative Assessment}

Black and Wiliam [3] defined formative assessment as "activities undertaken by teachers and by their students in assessing themselves that provide information to be used as feedback to modify teaching and learning activities." Thus, formative assessment aims to provide ongoing feedback not only for students to improve their learning but also for teachers to improve their teaching. Cook [8] asserted that formative assessment has two primary forms: unplanned and planned form. Unplanned or spontaneous formative assessments are incidental, unplanned comments and responses; coaching or impromptu feedback to students, such as oral feedback. Planed formative assessments consist of assignments such as quizzes, homework exercises used to assess student learning process and help them improve their learning.

\subsubsection{Summative Assessment}

In contrast to formative assessment, summative assessment aims to measure or summarize what students obtain after a period of a course. It usually occurs at the end of the course or unit of instruction [4]. Examples of summative assessments are final exams, entrance exams, and state tests. Besides the goal to examine the ability of students after a particular time of a course, Harlen and Gardner [12] also pointed out some aims of summative assessment are: To determine competence for special education programs such as gifted and talented education; To evaluate ability of students for advancement to next learning level; To provide employment guidance; To assess qualifications for awards.

According to Earl [10] while formative assessment is assessment for learning, summative assessment can be considered as an assessment of learning which "is designed to provide evidence of achievement to parents, other educators, the students themselves and sometimes to outside groups (e.g., employers, other educational 
institutions)" (p.55). This assessment usually has a farreaching and significant influence on students in the future.

\subsection{Group Work (Cooperative Learning)}

Group work or Cooperative learning is one of the most effective teaching approaches that significantly benefits learners [23]. Slavin [23] also pointed out many significant benefits of Cooperative learning on learners, including improving critical thinking skills, enhancing self-confidence and self-esteem, developing social skills, and engaging in learning. Johnson and Johnson [15] asserted that learners maximized their own and each other's learning when working in a group. They were also aware of having higher responsibility in learning. However, to apply Cooperative learning efficiently in the classroom, teachers should guarantee five Cooperative learning principles: positive interdependence, individual responsibility, face-to-face interaction, interpersonal and social skills, and group processing [16]. Regarding the first principle, Kagan [17] suggested that it might be seen as the most important principle that guaranteed Cooperative learning success. Each member in the group would try their best to fulfill the group's tasks and get the best results in learning. The second principle lets every member in the group have strong responsibility for their job in order to finish the group work successfully. The third and the fourth ones are principles that help create an interactional environment in the classroom, leading to improved speaking skills and sharing knowledge among students. In terms of the last principle, Kagan [17] emphasized teachers' role in teaching students' discussion skills, decision-making skills, effective leadership skills, trust-building skills, etc., so that students can easily discuss and fulfill their tasks in group-working environment. Group oral presentation also can be seen as one kind of Cooperative learning.

\subsection{Oral Presentations}

According to Chen [7], oral presentation in EFL context is a form of public speaking in which speakers use visual aids to present their ideas in a group or individually on a particular English topic. Mallette and Clare [19] stated that oral presentation is considered as "the most common method for presenting information and is usually done with a computer and projector" (p.161). In fact, most of the teachers who teach speaking for EFL learners use the oral presentation as an oral assessment, which is defined by Joughin [14] as "any assessment of learning which is conducted by the spoken word" (p.1), to assess students' speaking ability.

\subsubsection{Characteristics Of Oral Presentations}

There are many different elements that make an oral presentation become effective. According to Duddley-
Evans and Maggie [9], a good oral presentation's most important characteristics are structuring, visuals, voice, advanced signaling, and delivering a presentation. It is important to recognize that an effective oral presentation must have a clear structure. Structuring an oral presentation clearly helps listeners follow the presentation easily. In addition, when structuring an oral presentation, speakers should take the presentation's content and knowledge into account. Using visual aids in the presentation improves the effectiveness of the presentation. It makes listeners more engaged and interested in the presentation and helps speakers make their speech effectively. Regarding the voice element, Powell [22] asserted that "as a presenter, the ability to pace your speech and use your voice to create impact is the single most important skill you need. You will be more effective if you are in control of your voice by your use of stress, pausing, intonation, volume, and silence" (p.6). Thus, speaking clearly will make listeners easy to follow the presentation and more eager to listen. Besides, an oral presentation is successful when speakers know how to use signaling transitions so that listeners can follow the structure and catch the main points of the presentation. The last element is delivering the presentation. This is the way speakers deliver their presentations. According to Chikh and Dich [6], one presentation might be failed if the ways speakers deliver it is ineffective. Speakers have to maintain eye contact, use both non-verbal and verbal language, and have an appropriate tone of voice.

\subsubsection{Benefits of Oral Presentations}

According to Girard and Trapp [11], an oral presentation has many significant benefits on students' learning as follows: Enhancing interaction in the classroom; Engaging students in learning; Motivating students in learning the language; Improving students' communication skills and presentation skills significantly. King [18] also said that oral presentation helps learners use four language skills in an integrated way. Moreover, it promotes learner's autonomy and collaboration in learning.

\subsection{Previous Studies on Oral Presentations}

A variety of oral presentation studies have been conducted to investigate its impacts on learner's language ability. Chikh and Dich [6] also conducted a study investigate the impacts of an oral presentation on developing EFL students' communicative competence. The participants were EFL students and teachers at Tlemcen University. The results revealed that students recognized that oral presentation brought many significant benefits and usefulness for their learning. In addition, it also helped to develop the communicative competence of the learners, fulfill their future careers. In a study by Atmane [1], $40 \mathrm{EFL}$ students and $6 \mathrm{EFL}$ 
teachers at Bejaia University were surveyed and interviewed to identify the positive impacts of applying oral presentation in teaching communication and explore the students' attitude to this teaching assessment. The results found that oral presentation had positive effects on students' communicative skills. Besides, an oral presentation was also affected by many factors such as anxiety and teaching strategies.

\section{METHODOLOGY}

To investigate the use of oral presentation as an assessment in teaching English for students at Van Lang University, a questionnaire for EFL students and an interview for teachers teaching English at this university were used. A critical analysis of this assessment was given depending on the results of the questionnaire and the interview.

The study participants are 53 students studying in English courses at Van Lang University. The majority of them are third-year students. A questionnaire was distributed to them to investigate both the effectiveness of group oral presentation as an alternative assessment on their English competence and their perceptions on group oral presentations. Besides, five teachers teaching English at English Department of Van Lang University were interviewed to determine the teachers' perceptions of using this teaching assessment. They are teachers with over five years of teaching experience. The students' questionnaire (see appendix A) and teachers' interviews (see appendix B) are adapted from the study of Atmane [1]. They were then translated into Vietnamese so that both students and teachers could understand and gave their answers easily.

\section{RESULTS AND CRITICAL ANALYSIS}

\subsection{Results and Analysis from Students' Questionnaire}

\subsubsection{The Level and Attitude of Students in English Classroom}

From the chart below, in terms of English level, over half of the students, of which 31 students, answered that they are good at English. Besides, 10 students could not evaluate their English level. The others (12 students) confirmed that their English levels were low. Regarding students' shyness, over $50 \%$ of students said they are shy and less confident. 12 students are confident, and the others do not determine themselves. Regarding participation in the classroom, 30 students answered that they often participated in the classroom discussion. Only 7 students are not willing to participate in the discussion activities. The others didn't remember whether they took part in the discussion or not. In terms of the problems that students were facing when expressing themselves orally in English, up to 47 students, which occupies over $88 \%$ of the sample, agree with the statement, "I often have a problem expressing myself orally." These results indicate that although students at Van Lang University believe that their English level is not low and often discuss in the classroom, they are still shy and have many problems expressing ideas orally. This problem can be interpreted as good at grammar, writing, or listening skills, but not speaking skills. Or maybe students feel less confident due to inappropriate teaching strategies that were applied in the classroom. These results are similar to the results of Atmane's study [1].

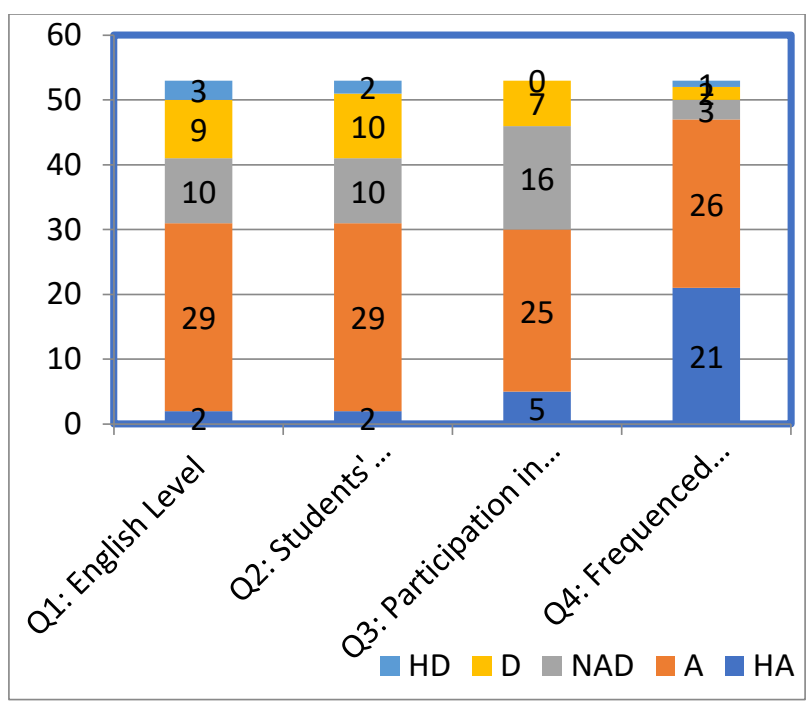

Figure 1 The English level and attitude of students in English classroom

\subsubsection{The Practice and Preference in Group Oral Presentations of Students}

As the questionnaire results, 20 students agreed that they have already given many GOPs before. Fourteen students were neutral with this statement. 19 students were never given GOPs before. Regarding the statement, "my teachers often asked me to prepare GOP projects, 26 students agreed with 18 neutral answers, and 9 disagreed answers. In terms of interest in giving GOPs, 20 students agreed, 20 students were neutral, the rest were not interested in giving GOPs. These results indicate that all students' changes to give GOPs in the classroom are still limited. This may be due to teachers not requiring students to give GOPs or to work in group work, and some students gave oral presentations on behalf of the whole group. As a result, some shy students do not give an oral presentation. From these results, teachers should consider assigning equal students in groups to give an oral presentation. Regarding students' interest in giving GOPs, only 13 students cannot give an oral presentation. These numbers indicate that the majority of students like participating in GOPs. These results imply that GOPs increases student engagement. It can be seen as an 
appropriate teaching method that helps students enhance their speaking skills.

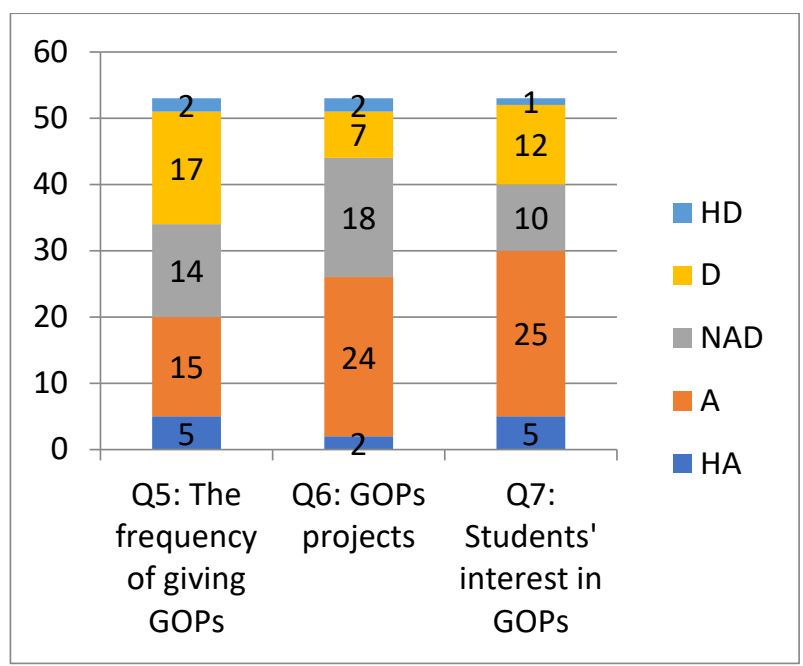

Figure 2 Students' practice and interest in GOPs

\subsubsection{Students' Problems and Opinions on GOPs}

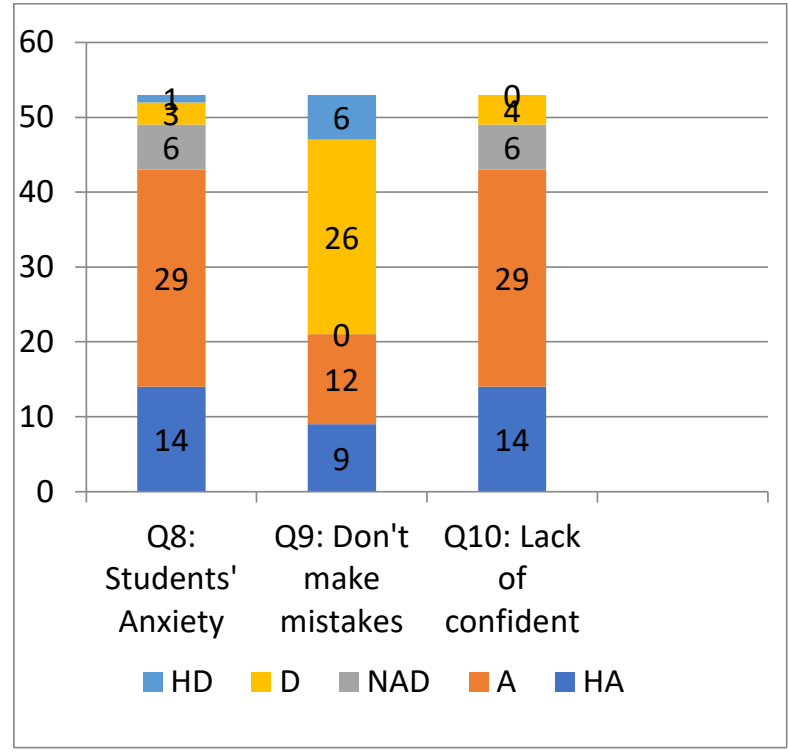

Figure 3 Students' problems on GOPs

The chart above shows that the majority of students, over $80 \%$ of the participants, agree with the statement, "I feel anxious or worried when I have to deal with an Oral Presentation." In response to the statement "I can give a presentation without any basic speaking skills and pronunciation mistakes," up to 32 students, nearly $60 \%$, disagreed with this, whereas 21 students agreed. Regarding confidence during giving oral presentations, as we can see from the chart, 43 students, over $80 \%$ of the sample, accept that they feel less confident when making oral presentations in the classroom. From these results, we can conclude that students make common mistakes such as pronunciation and basic speaking skills due to a lack of confidence and anxiety. This can result from students' insufficient speaking competence or can be from teaching techniques. Therefore, teachers should take teaching techniques and learning input into account in order to engage students and let them get rid of anxiety.

\begin{tabular}{|c|c|c|c|c|c|}
\hline $\begin{array}{l}\text { Questions/ } \\
\text { Statements }\end{array}$ & HA & $\mathbf{A}$ & NAD & D & HD \\
\hline $\begin{array}{lr}\text { Q11: } & \text { Oral } \\
\text { presentations give } \\
\text { me a chance to } \\
\text { practice my English }\end{array}$ & 9 & 34 & 8 & 2 & 0 \\
\hline $\begin{array}{l}\text { Q12: } \\
\text { presentations favor } \\
\text { the use of some } \\
\text { communication } \\
\text { techniques }\end{array}$ & 9 & 35 & 6 & 3 & 0 \\
\hline $\begin{array}{l}\text { Q13: Oral } \\
\text { Presentations } \\
\text { activities help me to } \\
\text { develop my } \\
\text { communication } \\
\text { skills }\end{array}$ & 6 & 33 & 11 & 3 & 0 \\
\hline $\begin{array}{l}\text { Q14: Oral } \\
\text { Presentations is an } \\
\text { effective way to } \\
\text { practice speaking }\end{array}$ & 13 & 32 & 7 & 1 & 0 \\
\hline $\begin{array}{l}\text { Q15: } \\
\text { communicate well, } \\
\text { Oral Presentations } \\
\text { should be } \\
\text { conducted regularly } \\
\text { in the classroom }\end{array}$ & 8 & 39 & 5 & 1 & 0 \\
\hline
\end{tabular}

Table 1. Students' opinion on GOPs

The table above illustrates the role of oral presentation in developing speaking skills and communication skills. As we can see from the table, from question 11 to 14 , most students agree with the significant role of GOPs in enhancing speaking competence. And the last question expresses students' opinions on applying GOPs in the classroom. These results reflect that most students like practicing GOPs, and they accept this teaching technique as an effective way to improve their speaking and communicative skills. In conclusion, group oral presentation can be seen as an efficient formative assessment to support Van Lang University's learning processes at present. 


\subsubsection{General Suggestions from Students on GOPS}

Some of the students have given suggestions to deal with problems they cope with when giving oral presentations. They said to reduce anxiety and confusion when preparing and making oral presentations. Teachers should teach them how to make a good oral presentation and guide them clearly. Besides, one student said, "due to lack of background knowledge on a given topic, we have difficulty preparing the oral presentation content." Thus, the oral presentation can be made after some units have enough knowledge and vocabulary about the topic. Teachers should require students to present topics ranging from easy to difficult ones. As one student suggested, "the topic should be easy at the beginning of the course and more difficult till the end of the course."

\subsection{Results and Analysis from Teachers' Interviews}

\subsubsection{The Performance of Students in GOPs}

In response to question number 2 , each teacher had a different comment on this issue. They said because students' English abilities and personalities were different from others, they performed differently in GOPs. There are 3 out of 5 teachers confirmed that their students felt shy and less confident when conducting an oral presentation in front of audiences. As a teacher said, "some of my students are shy and lose their words when they speak in front of the classroom." This teacher also commented as follows: "I don't think that shyness is the personality of these students because when I observe these students inside the classroom, they are very active." According to this teacher, shyness in giving oral presentations maybe comes from a lack of knowledge and ability in English. Another teacher added, "sometimes, some of my students just read words in the slide. This is not a presentation at all." However, the other teacher agreed that the majority of their students were good at English. They were confident when making oral presentations, even they made some mistakes.

\subsubsection{Teachers' role in the classroom}

In response to question number 3, all teachers confirmed that they played roles as guides, tutors, observers, and evaluators. As one teacher said:

"I usually give clear instruction on the given topics and presentation techniques to my students before requiring them to make group oral presentation. Before the presentation day, they submit their presentation slides to me, and I give them feedback. When they make a presentation, I often observe them, note some mistakes, and then give comments and fix their mistakes at the end of the presentation. Besides, other classroom groups are also expected to give peer-feedback on their classmates' work."

\subsubsection{Difficulties in Applying GOPs}

In response to question number 4 , most of the teachers confirmed that they had difficulty implementing group oral presentations in their classrooms. They listed some difficulties as follow:

- The large size of the class

- Lack of facility

- Inequality in students' English ability

- Lack of students' participation

- Cultural barriers leading to misunderstanding

- Unfamiliar topics

\subsubsection{Impacts of GOPs on students' communication skills}

In response to the three last questions, most teachers said that by making oral presentations regularly, students could improve their speaking skills, leading to better communication skills. As one teacher said:

"According to the speaking test results at the end of the course, I realize that many students in my classrooms applying group oral presentation have improved their speaking skills. They perform much better than at the beginning of the course."

Another teacher said, "most of my students are interested in making oral presentations. They like preparing and discussing in groups. They also pay a lot of attention in the classroom." From this result, we can see that most students have a positive attitude towards oral projects. However, one teacher said that giving too many GOPs in the classroom had some drawbacks. He said:

"If you require students to prepare and make too many GOPs, they will feel bored and under pressure. Even making too many GOPs can cause many negative problems. Students who have insufficient English ability will feel more and more unconfident, even having a fear of making an oral presentation".

\section{CONCLUSION}

This study was conducted to investigate the effectiveness of using group oral presentations as a formative assessment to develop students' speaking ability and support students' learning. The results from the questionnaire given to students and from interviews with teachers revealed that most students were willing to make an oral presentation and accepted that this method 
was ideal for improving their speaking skills and communicative skills. They also confirmed that this method would be effective if they had more chances to practice and under teachers' clear instruction. Through questionnaire, we also acknowledge that there were some difficulties in making GOPs of students such as lack of knowledge, lack of confidence, shyness, especially insufficient English ability of students. The teachers' perceptions pointed out some problems when applying this assessment in the classroom. In general, this assessment has been distributed into developing and improving students' speaking ability in particular, and students' learning ability in general. This method can be seen as an effective formative assessment for Van Lang University students.

The study still has limitations that need to be investigated in further studies. Firstly, the study sample is still small compared to the total students and teachers at University. Moreover, it will be more reliable if the students are divided into two groups, majoring in English and not majoring in English. If so, we can have a clear picture of students' perceptions and the impacts of GOPs on students' ability. Secondly, if we can triangulate the results with more research instruments such as observations from teachers, peer-feedback from students, the study's validity and reliability may be better.

\section{ACKNOWLEDGMENTS}

I want to express my gratitude to my instructor, the teachers, and the students who participated in this study. I am also grateful to the professor of the English Institution at Van Lang University who agreed to collaborate with me.

\section{REFERENCES}

[1] M.A. Atmane. Investigating the Role of Oral Presentation Projects in Enhancing EFL Learners' Oral Proficiency (Master's thesis). Bejaia University, Algeria. (2016).

[2] L. Bachman, A.S. Palmer. Language testing in practice. New York, NY: Oxford University Press. (1996).

[3] P. Black, D. Wiliam. Inside the black box: Raising standards through classroom assessment. Phi Delta Kappan. 92(1)(2010) 81-90.

[4] Brown, H. Douglas. Language assessment: Principles and classroom practices. White Plains, NY: Pearson Education. (2004).

[5] J.D. Brown, T. Hudson. The alternatives in language assessment. TESOL Quarterly. 32 (4)(1998) 653675.
[6] M.K. Chikh, Y. Dich. The Impact of Oral Presentations on Developing EFL Students' Communicative Competence: Case of Second Year LMD Students at the University of Tlemcen (Master's thesis). Tlemcen University, Algeria. (2016).

[7] L. Chen. A study of EFL graduate students' oral presentation anxiety. Unpublished master thesis, national Chung Cheng University, College of Education, Graduate Institute of the Department of Foreign Languages and Literature. (2009).

[8] H.G. Cook. Formative assessment: Best practices part 1 [PowerPoint slides]. Retrieved from http://flareassessment.org/resources/PA PD Form \%20Assess_Ppt_1_rev050709.pdf . (2009).

[9] T. Dudley-Evans, J.S.J. Maggie. Developments in English for specific purposes: A multi-disciplinary approach. Cambridge: CUP. (1998).

[10] S.E. Earl, S.E. Staff and peer assessment: measuring an individual's contribution group performance. Assessment and Evaluation in Higher Education. 11(1986) 60-69.

[11] M.P. Girard, P. Trapp. An exploratory study of class presentations and peer evaluations: Do students perceive benefits? Academy of Educational Leadership Journal. 15(1)(2011) 77-94.

[12] W. Harlen, J. Gardner. Assessment to support learning. In J. Gardner, W. Harlen, L. Hayward, G. Stobart, \& M. Montgomery (Eds.), developing teacher assessment. New York, NY: Open University Press.(2010) 15-28.

[13] Hughes, A. Testing for language teachers. Cambridge, MA: Cambridge University Press. (2003).

[14] G. Joughin. "A short guide to oral assessment" version 2, 17 February 2010, CEDIR, University of Wollongong, Leeds, metropolitan University. (2020) 1-22.

[15] D.W. Johnson, R.T. Johnson. Learning together and alone: Cooperative, competitive, and individualistic learning (5th Eds.). Boston: Allyn and Bacon. (1999).

[16] D.W. Johnson, R.T. Johnson. (2008). Social Interdependence Theory and Cooperative Learning: The Teacher's Role. In R. M. Gillies, A. Ashman \& J. Terwel (Eds.), Teacher's Role in Implementing Cooperative Learning in the Classroom. New York, U.S.A: Springer. (2008) 9-37.

[17] S. Kagan. Cooperative learning. San Clemente, California: Kagan Publishing. (1994). 
[18] J. King. Preparing EFL learners for oral presentations. Dong Hwa Journal of Humanistic Studies. 4 (2002) 401-418.

[19] L. Mallete, B. Clare. Writing for Conferences: A Handbook for Graduate Students and Faculty. USA: Greenwood. (2011).

[20] F.M. Mihai. Assessing English language learners in the content areas: A research-into practice guide for educators. Ann Arbor, MA: University of Michigan Press.(2010).

[21] Ministry of Education and Training of Vietnam [MOET]. Development Strategy from 2009 to year
2020 for the Cause of Industrialization and Modernization of Vietnam. Hanoi: Vietnamese Government. (2009).

[22] M. Powell. Presenting in English: How to Give Successful Presentations. USA: Heinle. (2002).

[23] R.E. Slavin. Cooperative learning. Boston: Allyn and Bacon. (1995).

[24] S. Živković. The Importance of Oral Presentations for University Students. Mediterranean Journal of Social Sciences MCSER Publishing, Rome-Italy. 5(19) (2014) 468-475.

\section{APPENDIXES}

\section{Appendix A: Students' Questionnaire}

\section{Dear Students,}

We are conducting a research for the fulfilment of a master degree in Linguistics (TESOL). This Questionnaire is designed to support our investigation on "The Effects of Using Group Oral Presentation Projects, in EFL

Context, to Enhance Learners' English ability". Thus, you are kindly asked to answer the following questions by selecting the answer which best reflects your opinion.

Your contribution is appreciated.

Tick the appropriate answer from 1. Highly Agree (HA) to 5. Highly Disagree (HD) for each statement/ question in the table below.

1. Highly Agree: HA

2. Agree: A

3. Neither Agree nor Disagree: NAD

4. Disagree: D

5. Highly Disagree: HD

\begin{tabular}{|c|c|c|c|c|c|c|}
\hline Item & Statement / Question & HA & $\mathbf{A}$ & NAD & D & HD \\
\hline 1 & I have a good level in English & & & & & \\
\hline 2 & I am a shy learner & & & & & \\
\hline 3 & I often take part in classroom discussion & & & & & \\
\hline 4 & I often have a problem expressing myself orally & & & & & \\
\hline 5 & I have already given many group oral presentations & & & & & \\
\hline 6 & $\begin{array}{l}\text { My teachers often ask me to prepare oral presentation } \\
\text { projects }\end{array}$ & & & & & \\
\hline 7 & I like dealing with group oral presentations assignments & & & & & \\
\hline 8 & $\begin{array}{l}\text { I feel anxious/worried when I have to deal with an group } \\
\text { oral presentation }\end{array}$ & & & & & \\
\hline 9 & $\begin{array}{l}\text { I can give a presentation without any basic speaking } \\
\text { skills and pronunciation mistakes }\end{array}$ & & & & & \\
\hline 10 & $\begin{array}{l}\text { I hesitate when I have to speak in public because I lack } \\
\text { confidence }\end{array}$ & & & & & \\
\hline 11 & $\begin{array}{l}\text { Group oral presentations give me a chance to practice my } \\
\text { English }\end{array}$ & & & & & \\
\hline 12 & $\begin{array}{l}\text { Group oral presentations favour the use of some } \\
\text { communication techniques }\end{array}$ & & & & & \\
\hline 13 & $\begin{array}{l}\text { Group oral presentations activities help me to develop } \\
\text { my communication skills }\end{array}$ & & & & & \\
\hline 14 & $\begin{array}{l}\text { Group oral presentations is an effective way to } \\
\text { practice speaking }\end{array}$ & & & & & \\
\hline 15 & $\begin{array}{l}\text { To communicate well, group oral presentations } \\
\text { should be conducted regularly in the classroom }\end{array}$ & & & & & \\
\hline
\end{tabular}


General suggestions on group oral presentation:

Thanks for your contribution!

\section{Appendix B: Teachers' Interview}

Dear Teachers,

This interview questions aim at collecting information about the effects of using group oral presentation as a formative assessment in EFL Classrooms to enhance and develop learners' oral communication performance. We would be very grateful if you answer the following questions which will help us in our research for the fulfillment of Master degree in Linguistics (TESOL). Your point of view is very important.

Please answer the questions below.

1. How long have you been teaching English?

2. Based on your experience as a teacher of English, how do you perceive your students'

performance in group oral presentations? Please explain.

3. Generally, what is your role during an oral presentation session? Please provide as many details as possible.

4. Can you name difficulties when applying group oral presentation in your classrooms?

5. Most literature in the field of oral communication shows that group oral presentations in EFL

classroom have a positive impact on students' oral communicative skills. What is your comment on the matter?

6. Many approaches to foreign language teaching stress the fact that conducting oral presentation projects in

EFL classrooms helps to form communicatively competent students. Comment!

7. In general, do you think that group oral presentation can be seen as a good assessment to support students' learning, especially students' speaking competence? Why?

Thank you for your collaboration! 